\title{
均質化法による多孔質吸音材の等価特性の導出*
}

\author{
山本崇史 ${ }^{* 1}$, 丸山新一 ${ }^{* 1}$, 泉井一浩 ${ }^{* 2}$, 西脇眞二 ${ }^{* 2}$, 寺田賢二郎 $* 3$
}

\section{Equivalent Properties of Sound Absorbing Poroelastic Material Using the Homogenization Method}

\author{
Takashi YAMAMOTO*1, Shinichi MARUYAMA, \\ Kazuhiro IZUI, Shinji NISHIWAKI and Kenjiro TERADA \\ *1 Nissan Motor Co., Ltd. \\ 560-2, Okatsukoku, Atsugi-shi, Kanagawa, 243-0192, Japan
}

\begin{abstract}
In this paper we propose a new method to derive macroscopic equivalent properties of sound absorbing poroelastic material using the homogenization method. Assuming that the microscopic geometry of the poroelastic material is periodic, this method directly provides a macroscopic elastic tensor for the solid phase, an equivalent density and a bulk modulus for the fluid phase. In the derivation of the macroscopic properties, we perform multiphysics analysis of several phenomena arising in the sound absorption by the poroelastic material, namely, elastic motion of the solid phase, compressible viscous fluid flow in the fluid phase, temperature distribution in the fluid phase, and coupled effects between solid and fluid phases. The equivalent density is obtained by averaging the characteristic function of the fluid flow, and the equivalent bulk modulus is calculated by averaging the characteristic function of the temperature distribution. Several numerical models with simple microscopic geometries are employed to compare the macroscopic properties represented in the numerical solutions obtained using the proposed method with solutions obtained analytically. We demonstrate that the proposed method can provide solutions with sufficient accuracy and that the solutions converge to analytically obtained solutions as the value of the discretization parameter used in the numerical models is made smaller.
\end{abstract}

Key Words : Sound and Acoustic, Simulation, Damping, Sound Absorption, Homogenization, Poroelastic Material

\section{1. 緒言}

自動車の室内における静肃性の向上は, 乗車中の快適性を高める重要な要素であり, その一方策としてフロア カーペットなどの多孔質吸音材が使用されている. 多孔質吸音材の動的特性の予測手法については様々な研究が 行われてきているが, 近年 Kang と Bolton ${ }^{(1)}$, Easwaran ${ }^{(2)} ら$, あるいは Attala $~^{\left({ }^{(3)}\right.}$ が有限要素法による解析手法 を提案しており，任意の形状および境界条件を考慮した数值解析が可能になっている．これらの研究ではいずれ も Biot ${ }^{(4)(5)}$ により提案されたモデルが適用されている.

Biot のモデルは当初, 固体相と流体相が混在する土壌や岩盤などの動的特性を表現するために提案されたもの である. 各相の巨視的な特性を用いてモデル化されており, 固体相は線形弾性体, 流体相は粘性流体の特性により 表現されている. 流体相の媒質は液体を仮定していたので, 特性としては粘性による減衰のみ考慮されていたが, 媒質が気体の場合にも適用できるよう, Johnson ${ }^{(6)}$, Champoux ${ }^{(7)}$, Allard ${ }^{(8)}$ によって, 熱散逸による減衰も考 慮されたモデルが提案されている. 多孔質吸音材には現在, このモデルが適用される場合が多い. しかし, Biot の モデルにおいて流体相の特性は, 粘性流体の微小円管内の挙動に対する理論解に基づき導出されており，任意の

* 原稿受付 2010 年 2 月 22 日

*1 正員, 日産自動車 (株)（干 243-0192 神奈川県厚木市岡津古久 560-2）

*2 正員, 京都大学大学院工学研究科機械理工学専攻 ( $\bar{T}$ 606-8501 京都府京都市左京区吉田本町)

*3 正員, 東北大学大学院工学研究科土木工学専攻 ( ₹ 980-8579 宮城県仙台市青葉区荒巻字青葉 6-6-06)

Email: tks-yamamoto@mail.nissan.co.jp 
断面形状を有する流路への展開については数理的な厳密さに欠ける. また，Biot モデルに含まれる流れ抵抗など の8つのマクロなパラメータは, 実験により同定しなければならないのが現状である.

一方，多孔質体のミクロ構造に均質化法を適用し，マクロスケールにおける等価特性值を導出することを目的 とした研究が，これまでにも行われている．例えば浸透流の問題に対して, Auliault ら ${ }^{(9)}$ は, 多孔質体の固体相 が剛壁の場合についてマクロな透水係数を導き，実験による検証を行っている．また Terada ${ }^{(10)}$ は，固体相と 流体相の連成系として定式化している. Burridge ら ${ }^{(11)}$ は, 多孔質吸音材のミクロスケールにおける平衡式执よび 構成式から, マクロスケールにおける等価特性值を導出し, Biot のモデルにおける特性值と比較している. しか し，流体相で発生した熱が固体相へ散冕することによる減衰を考慮しておらず，流体相の特性の一つである体積 弾性率が実際よりも大きく評価されている.

そこで本論文では, 流体相における粘性および熱の散逸による減衰の両方を考慮した上で, 多孔質吸音材の微 視構造に漸近展開法による均質化法を適用し, 微視構造から多孔質吸音材の動的特性の予測に必要な等価特性を

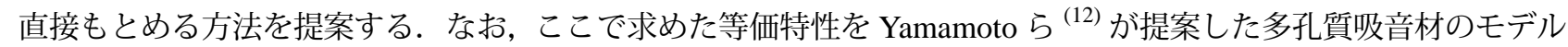
に適用することで, 吸音率などのマクロな特性を求めることができる.

まず 2 章では Biot のモデルについて概説し，現在考えられる問題点について説明する. 次に 3 章で, 本研究で 適用する支配方程式を示し，4章において漸近展開法を用いた均質化法による定式化を行い等価特性を求める. 最 後に 5 章で, 等価特性の提案手法による数值解と理論解を比較し, 手法の有効性を検証する.

以下で用いる変位や圧力などの状態量は全て, 角振動数 $\omega$ で微小振幅の調和振動をするものと仮定し, 断りの ない限り周波数領域で表すものとする. また, 流体相の圧力, 温度, 質量密度に関しては平衡状態（圧力 $P_{0}$, 温 度 $T_{0}$, 質量密度 $\rho_{0}^{f}$ ) からの変動量を表す.なお, 固体相は線形弾性体, 流体相は圧縮性の粘性流体で構成され, 流体相は全て連結しているものとする.

\section{Biot のモデル}

吸音を目的とした多孔質体に現在適用されている Biot のモデルについて概略を説明する．流体相に関しては， 近年広く使用されている Allard ら ${ }^{(8)}$ のモデルにより記述する.

固体相および流体相の運動方程式は, 固体相の変位 $u_{i}^{s}$ と, 流体相の固体相に対する相対変位 $U_{i}^{f}$ を用いて, そ れぞれ以下のように表される.

$$
\begin{aligned}
-\bar{\rho} \omega^{2} u_{i}^{s}-\phi \rho_{0}^{f} \omega^{2} U_{i}^{f} & =\frac{\partial \sigma_{i j}^{s}}{\partial x_{j}}+\frac{\partial \sigma_{i j}^{f}}{\partial x_{j}} \\
-\phi \rho_{0}^{f} \omega^{2} u_{i}^{s}-\rho^{f c} \omega^{2} U_{i}^{f} & =\frac{\partial \sigma_{i j}^{f}}{\partial x_{j}}
\end{aligned}
$$

ここで, $\sigma_{i j}^{s}$ は固体相の応力, $\sigma_{i j}^{f}$ は流体相の応力で流体相の体積分率 (空孔率) $\phi$ および流体相の圧力 $p^{f}$ と $\sigma_{i j}^{f}=-\phi p^{f} \delta_{i j}$ の関係がある. なお， $\delta_{i j}$ は Kroneckerのデルタ関数である． $\bar{\rho}$ は多孔質体の平均質量密度で $\rho^{s}$ を 固体相の質量密度とすると $(1-\phi) \rho^{s}+\phi \rho_{0}^{f}$ と表される. $\rho^{f c}$ は固体相と流体相の境界における粘性減衰を考慮し た流体相の等価密度で,

$$
\rho^{f c}=\rho_{0}^{f} \alpha_{\infty}\left[1+\frac{\sigma \phi}{j \omega \rho_{0}^{f} \alpha_{\infty}} G(\omega)\right], G(\omega)=\left(1+\frac{4 j \omega v}{\Lambda^{2}} \frac{\rho^{f 2} \alpha_{\infty}^{2}}{\sigma^{2} \phi^{2}}\right)^{1 / 2}
$$

と表される，ここで， $v$ は動粘性係数， $\sigma, \alpha_{\infty}, \Lambda$ はそれぞれ空気流れ抵抗, 迷路度, 粘性代表長さと呼ばれるパ ラメータである.

また，固体相および流体相の構成式はそれぞれ次式で与えられる.

$$
\begin{aligned}
& \sigma_{i j}^{s}=\left[(P-2 N) \varepsilon_{k k}^{s}+Q \varepsilon_{k k}^{f}\right] \delta_{i j}+2 N \varepsilon_{i j}^{s} \\
& \sigma^{f}=Q \varepsilon_{k k}^{s}+R \varepsilon_{k k}^{f}
\end{aligned}
$$

ここで, $N$ は固体相のせん断剛性， $\varepsilon_{i j}^{s}, \varepsilon_{i j}^{f}$ はそれぞれ固体相および流体相の歪みである. $P, Q, R$ については近 
似的に以下の式で表すことができる.

$$
\begin{aligned}
& P \simeq \frac{(1-\phi)^{2}}{\phi} K^{f}+K^{s}+\frac{4}{3} N \\
& Q \simeq(1-\phi) K^{f} \\
& R \simeq \phi K^{f}
\end{aligned}
$$

ただし， $K^{s}$ は固体相の体積弾性率， $K^{f}$ は Allard ${ }^{(8)}$ が提案した熱の固体相への散逸による減衰を含んだ流体相 の等価体積弾性率で, 比熱比 $\gamma$, 平衡状態の圧力 $P_{0}$, 温度拡散率 $v^{\prime}$ を用いて

$$
K^{f}=\frac{\gamma P_{0}}{\gamma-(\gamma-1)\left[1+\frac{8 v^{\prime}}{j \omega \Lambda^{\prime 2}} H(\omega)\right]^{-1}}, H(\omega)=\left(1+\frac{j \omega \Lambda^{\prime 2}}{16 v^{\prime}}\right)^{1 / 2}
$$

と表される.ここで, $\Lambda^{\prime}$ は温度代表長さと乎ばれるパラメータである.

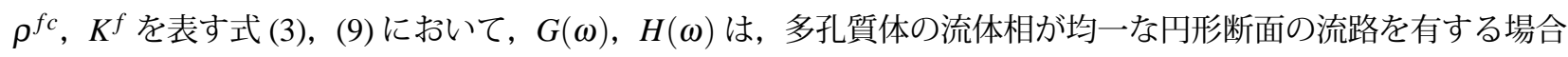
の理論解に近くなるよう定められた経験的な関数であり，パラメータを用いた直接的な式表現である反面，厳密性 に欠ける. また, 固体相に関しては $K^{s}, N, \rho^{s}$ の 3 つ, 流体相に関しては $\phi, \sigma, \alpha_{\infty}, \Lambda, \Lambda^{\prime}$ の 5 つのパラメー タを実験的に同定しなければならないのが現状である.

\section{3. 支配 方 程 式}

多孔質吸音材のミクロスケールにおける支配方程式について説明する．まず，固体相の支配方程式は弾性テン ソルを $c_{i j k l}^{s}$ とすると, 以下に示す式で表される.

$$
\begin{aligned}
-\rho^{s} \omega^{2} u_{i}^{s} & =\frac{\partial \sigma_{i j}^{s}}{\partial x_{j}} \\
\sigma_{i j}^{s} & =c_{i j k l}^{s} \varepsilon_{k l}^{s} \\
\varepsilon_{k l}^{s} & =\frac{1}{2}\left(\frac{\partial u_{k}^{s}}{\partial x_{l}}+\frac{\partial u_{l}^{s}}{\partial x_{k}}\right)
\end{aligned}
$$

次に, 流体相の速度を $v_{i}^{f}$, 質量密度を $\delta^{f}$, 温度を $\tau^{f}$ とすると, 流体相に関する質量保存則および状態方程式 はそれぞれ次式で表される.

$$
\begin{array}{r}
\rho_{0}^{f} \frac{\partial v_{i}^{f}}{\partial x_{i}}+j \omega \delta^{f}=0 \\
\frac{p^{f}}{P_{0}}=\frac{\delta^{f}}{\rho_{0}^{f}}+\frac{\tau^{f}}{T_{0}}
\end{array}
$$

また，流体相の流れ場に関する支配方程式は微小振幅であることを考慮すると，線形化された Navier-Stokes の 方程式で表される.すなわち, 粘性係数を $\mu^{f}$ とすると以下のようになる.

$$
\begin{aligned}
\rho^{f} j \omega v_{i}^{f} & =\frac{\partial \sigma_{i j}^{f}}{\partial x_{j}} \\
\sigma_{i j}^{f} & =-p^{f} \delta_{i j}+2 \mu^{f} \dot{\varepsilon}_{i j}^{f}-\frac{2}{3} \mu^{f} \delta_{i j} \dot{\varepsilon}_{k k}^{f} \\
\dot{\varepsilon}_{i j}^{f} & =\frac{1}{2}\left(\frac{\partial v_{i}^{f}}{\partial x_{j}}+\frac{\partial v_{j}^{f}}{\partial x_{i}}\right)
\end{aligned}
$$

そして, 固体相の比熱は流体相の比熱に比して十分大きく, 平衡状態での温度 $T_{0}$ を維持すると仮定すると, 温 
度場は流体相のみを考慮すればよく, 支配方程式は熱力学の第一法則より次式のように表せる.

$$
\begin{aligned}
-\frac{\partial q_{i}^{f}}{\partial x_{i}} & =j \omega \rho_{0}^{f} C_{v}^{f} \tau^{f}+\left(j \omega \rho_{0}^{f} R \tau^{f}-j \omega p^{f}\right) \\
q_{i}^{f} & =-\kappa_{i j}^{f} \frac{\partial \tau^{f}}{\partial x_{j}}
\end{aligned}
$$

ここで, $C_{v}^{f}$ は定積比熱, $R$ は気体定数, $q_{i}^{f}$ は熱流速, $\kappa_{i j}^{f}$ は熱伝導率である. なお, 式 (18) の右辺第一項は単位 体積あたりの内部エネルギー変化，第二，三項は状態方程式より外部仕事を表している.

最後に, 固体相と流体相の境界 $\Gamma^{s f}$ における境界条件は, 速度, 境界垂直方向の応力, および温度の連続性か ら, 以下の式で与えられる.

$$
\begin{aligned}
j \omega u_{i}^{s} & =v_{i}^{f} \\
\sigma_{i j}^{s} n_{j}^{s}+\sigma_{i j}^{f} n_{j}^{f} & =0 \\
\tau^{f} & =0
\end{aligned}
$$

ここで, $n_{i}^{s}, n_{i}^{f}$ はそれぞれ, $\Gamma^{s f}$ に立てた固体相, 流体相の領域外向きの単位法線べクトルである.

\section{4. 漸近展開法に基づく吸音材の均質化特性}

2 章で述べたように現在適用されている Biot のモデルでは, 流体相に関して $\phi, \sigma, \alpha_{\infty}, \Lambda, \Lambda^{\prime}$ の值をパラメー タとして用いることが一般的であるが, 式 (3) および (9) からも明らかなように, 空孔率 $\phi$ と等価密度 $\rho^{f c}$ および 等価体積弾性率 $K^{f}$ の值が分かれば良い. ここでは多孔質体の微視構造に漸近展開法に基づく均質化法を適用し, 流体相の $\rho^{f c}, K^{f}$ および固体相の弾性テンソル $c_{i j k l}^{s}$ も含め, 微視構造から数理的に求めることを考える.

\section{$4 \cdot 1$ スケーリング}

ミクロスケール，マクロスケールの代表長さをそれぞれ $l, L$ とし，その比を $\varepsilon=l / L$ とする．また，マクロス ケールにおける空間変数を $x$, ミクロスケールにおける空間変数を $y=x / \varepsilon(\varepsilon \ll 1)$ とする. そして微視構造は周 期的であると仮定し，その単位領域（ユニットセル）を $Y$ とする. ここでは，l はユニットセルの大きさ， $L$ は多 孔質体における波長の長さとする. 一般的な吸音材料では, 空孔の大きさは数 $\mu \mathrm{m}$ から数百 $\mu \mathrm{m}$ であり, ユニッ トセルの大きさはその数倍程度でほぼ同じオーダーと考えられる. また，対象とする周波数の上限を $6.4 \mathrm{kHz}$ とす ると，その上限周波数において音の波長は空気中では約 $50 \mathrm{~mm}$ で，吸音材料内部では一般にそれより波長は若干 短くなるもののオーダーは同じである ${ }^{(13)}$. したがって,$\varepsilon$ としては $1.0 \times 10^{-2}$ あるいはそれ以下のオーダーとな り, スケールの分離ができることが分かる.

多孔質体による吸音は主として流体相において, 固体相との境界付近で生じる粘性減衰と熱散逸に起因する．こ れらの効果が卓越する領域の大きさをそれぞれ粘性境界層厚さ $\delta_{v}$, 温度境界層厚さ $\delta_{t}$ といい, それぞれ以下のよ うに定義される。

$$
\delta_{v}=\left(\frac{\mu^{f}}{\rho_{0}^{f} \omega}\right)^{1 / 2}, \delta_{t}=\left(\frac{\kappa_{0}^{f}}{\rho_{0}^{f} \omega C_{p}^{f}}\right)^{1 / 2}
$$

ここで, $\kappa_{0}^{f}$ は流体の媒質の特性としての熱伝導率である. これらの大きさは, 多孔質体に吸音効果がある場合, 空孔の大きさのスケールにほぼ等しい. 実際, 周波数範囲を $50 \mathrm{~Hz}$ から $6.4 \mathrm{kHz}$ とすると, $\delta_{v}$ は $18 \mu \mathrm{m} \sim 205 \mu \mathrm{m}$, $\delta_{t}$ は $21 \mu \mathrm{m} \sim 243 \mu \mathrm{m}$ となり, おおよそ空孔サイズと同じ $O(l)$ となることが分かる. このことを考慮すると, 式 (23) から以下の関係式を得ることができる.

$$
O\left(\frac{\mu^{f} / L^{2}}{\rho_{0}^{f} \omega}\right)=O\left(\frac{\kappa_{0}^{f} / L^{2}}{\rho_{0}^{f} \omega C_{p}^{f}}\right)=O\left(\varepsilon^{2}\right)
$$

これより, 式(16) と (19) はそれぞれ次のように書き直すことができる.

$$
\begin{aligned}
\sigma_{i j}^{f} & =-p^{f} \delta_{i j}+2 \varepsilon^{2} \mu^{f} \dot{\varepsilon}_{i j}^{f}-\frac{2}{3} \varepsilon^{2} \mu^{f} \delta_{i j} \dot{\varepsilon}_{k k}^{f} \\
q_{i}^{f} & =-\varepsilon^{2} \kappa_{i j}^{f} \frac{\partial \tau^{f}}{\partial x_{j}}
\end{aligned}
$$


これは，粘性による減衰や熱の拡散はミクロレベルで生じるためマクロな視点では見えないことを意味している. すなわち, 粘性による速度への影響, あるいは熱の拡散による温度への影響は短時間 ( $\varepsilon^{2}$ のオーダー) で現れるた め，マクロに見ればその領域の速度や温度は均一と見なせるということである.

\section{2 漸近展開}

状態量 $u_{i}^{s}, v_{i}^{f}, p^{f}, \tau^{f}, \delta^{f}$ に対して, 次式のような漸近展開形の解を仮定する.

$$
\begin{aligned}
u_{i}^{s} & =u_{i}^{s(0)}(\boldsymbol{x}, \boldsymbol{y})+\varepsilon u_{i}^{s(1)}(\boldsymbol{x}, \boldsymbol{y})+\varepsilon^{2} u_{i}^{s(2)}(\boldsymbol{x}, \boldsymbol{y})+\cdots \\
v_{i}^{f} & =v_{i}^{f(0)}(\boldsymbol{x}, \boldsymbol{y})+\varepsilon v_{i}^{f(1)}(\boldsymbol{x}, \boldsymbol{y})+\varepsilon^{2} v_{i}^{f(2)}(\boldsymbol{x}, \boldsymbol{y})+\cdots \\
p^{f} & =p^{f(0)}(\boldsymbol{x}, \boldsymbol{y})+\varepsilon p^{f(1)}(\boldsymbol{x}, \boldsymbol{y})+\varepsilon^{2} p^{f(2)}(\boldsymbol{x}, \boldsymbol{y})+\cdots \\
\tau^{f} & =\tau^{f(0)}(\boldsymbol{x}, \boldsymbol{y})+\varepsilon \tau^{f(1)}(\boldsymbol{x}, \boldsymbol{y})+\varepsilon^{2} \tau^{f(2)}(\boldsymbol{x}, \boldsymbol{y})+\cdots \\
\delta^{f} & =\delta^{f(0)}(\boldsymbol{x}, \boldsymbol{y})+\varepsilon \delta^{f(1)}(\boldsymbol{x}, \boldsymbol{y})+\varepsilon^{2} \delta^{f(2)}(\boldsymbol{x}, \boldsymbol{y})+\cdots
\end{aligned}
$$

ここで, 右辺における全ての項は $y$ について周期的（ $Y$-periodic）である. なお, 多孔質体の問題においても漸近 展開形の解が成り立つことは, Gilbert $ら^{(14)}$ や Clopeau $~^{(15)}$ が two-scale 収束論を適用し数学的に明らかにして いる.

漸近展開に基づく均質化法の一般的な手順 ${ }^{(16)}$ にしたがい, $u_{i}^{s}, v_{i}^{f}, p^{f}, \tau^{f}, \delta^{f}$ の漸近展開形を式 (10)〜式 (22)

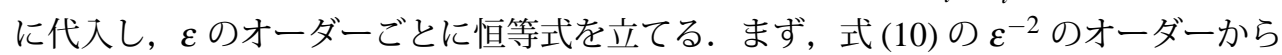

$$
\frac{\partial \sigma_{i j}^{s(-1)}}{\partial y_{j}}=0
$$

を得ることができる. また，式(10), (15), (13)の $\varepsilon^{-1}$ のオーダーから

$$
\begin{aligned}
\frac{\partial \sigma_{i j}^{s(-1)}}{\partial x_{j}}+\frac{\partial \sigma_{i j}^{s(0)}}{\partial y_{j}} & =0 \\
\frac{\partial \sigma_{i j}^{f(0)}}{\partial y_{j}} & =0 \\
\frac{\partial v_{i}^{f(0)}}{\partial y_{i}} & =0
\end{aligned}
$$

が成り立つ. さらに，(15)，(16)，(18)，(13)，(14), (20), (22)の $\varepsilon^{0}$ のオーダーから以下に示す式を得ることがで きる.

$$
\begin{gathered}
\rho_{0}^{f} j \omega v_{i}^{f(0)}=\frac{\partial \sigma_{i j}^{f(0)}}{\partial x_{j}}+\frac{\partial \sigma_{i j}^{f(1)}}{\partial y_{j}} \\
\sigma_{i j}^{f(0)}=-p^{f(0)} \delta_{i j} \\
-\frac{\partial q_{i}^{f(1)}}{\partial y_{i}}=j \omega \rho_{0}^{f} C_{p}^{f} \tau^{f(0)}-j \omega p^{f(0)} \\
\rho_{0}^{f}\left[\frac{\partial v_{i}^{f(0)}}{\partial x_{i}}+\frac{\partial v_{i}^{f(1)}}{\partial y_{i}}\right]+j \omega \delta^{(0)}=0 \\
\frac{p^{f(0)}}{P_{0}}=\frac{\delta^{(0)}}{\rho_{0}^{f}}+\frac{\tau^{f(0)}}{T_{0}} \\
j \omega u_{i}^{s(0)}=v_{i}^{f(0)} \\
\tau^{f(0)}=0
\end{gathered}
$$

\section{$4 \cdot 3$ 固体相の境界値問題}

固体相に関しては, Terada ${ }^{(10)} や$ Burridge ら ${ }^{(11)}$ における定式化と同じであることから結果を簡潔に示す. まず, 式 (27)より $u^{s(0)}$ が, また式 (29) と (32)より $p^{f(0)}$ が $\boldsymbol{x}$ のみ関数であることが分かる. また, 固体相の 
変位 $u_{i}^{s(1)}$ は, 線形性を考慮すると, $\chi_{i}^{k l}(\boldsymbol{y}), \eta_{i}(\boldsymbol{y})$ を変位に関する $Y$-periodic な特性関数として次のように書ける.

$$
u_{i}^{s(1)}=-\chi_{i}^{k l}(\boldsymbol{y}) \varepsilon_{k l}^{s(0)}-\eta_{i}(\boldsymbol{y}) p^{f(0)}(\boldsymbol{x})
$$

なお， $\varepsilon_{k l}^{s(0)}(\boldsymbol{x})=\frac{1}{2}\left(\frac{\partial u_{k}^{s(0)}(\boldsymbol{x})}{\partial x_{l}}+\frac{\partial u_{l}^{s(0)}(\boldsymbol{x})}{\partial x_{k}}\right)$ である.これを式 (28) に代入し Galerkin 法を適用すると，以下に示す 式を導出することができる.

$$
\int_{Y}\left[\left(c_{i j k l}^{s}-c_{i j p q}^{s} \frac{\partial \chi_{p}^{k l}(\boldsymbol{y})}{\partial y_{q}}\right) \varepsilon_{k l}^{s(0)}-c_{i j k l}^{s} \frac{\partial \eta_{k}(\boldsymbol{y})}{\partial y_{l}} p^{f(0)}(\boldsymbol{x})\right] \frac{\partial \delta u_{i}^{s}}{\partial y_{j}} d Y=\int_{\Gamma^{s f}}-p^{f(0)}(\boldsymbol{x}) \delta_{i j} n_{j}^{s} \delta u_{i}^{s} d \Gamma
$$

特性関数 $\chi_{i}^{k l}(\boldsymbol{y})$ は, 上式において $\varepsilon_{k l}^{s(0)}=1, p^{f(0)}=0$ として得られる

$$
\int_{Y}\left(c_{i j k l}^{s}-c_{i j p q}^{s} \frac{\partial \chi_{p}^{k l}(\boldsymbol{y})}{\partial y_{q}}\right) \frac{\partial \delta u_{i}^{s}}{\partial y_{j}} d Y=0
$$

より求めることができる，ただし，剛体変位を除くために $\int_{Y} \chi_{i}^{k l}(\boldsymbol{y}) d Y=0$ の条件を付加する. 同様にして, 特性 関数 $\eta_{i}(\boldsymbol{y})$ は, $\varepsilon_{k l}^{s(0)}=0, p^{f(0)}=1$ とおいて得られる

$$
\int_{Y} c_{i j k l}^{s} \frac{\partial \eta_{k}(\boldsymbol{y})}{\partial y_{l}} \frac{\partial \delta u_{i}^{s}}{\partial y_{j}} d Y=\int_{\Gamma^{s f}} \delta_{i j} n_{j}^{s} \delta u_{i}^{s} d \Gamma
$$

より求めることができる. ここでも, 剛体変位を除くために $\int_{Y} \eta_{i}(\boldsymbol{y}) d Y=0$ の条件を付加する.

\section{4 流体相の流れ場の境界值問題}

$\varepsilon^{0}$ のオーダーにおける流体相の固体相に対する相対速度

$$
w_{i}^{f(0)}=v_{i}^{f(0)}-j \omega u_{i}^{s(0)}(\boldsymbol{x})
$$

を式 (31), (30), (36) に代入すると, 流体相の流れ場に関して, 次に示すミクロスケールにおける境界値問題を得 ることができる.

$$
\begin{aligned}
\rho_{0}^{f} j \omega w_{i}^{f(0)}+\frac{\partial p^{f(1)}}{\partial y_{i}}-\mu^{f} \frac{\partial^{2} w_{i}^{f(0)}}{\partial y_{j} \partial y_{j}}-\frac{1}{3} \mu^{f} \frac{\partial}{\partial y_{i}} \frac{\partial w_{k}^{f(0)}}{\partial y_{k}} & =\rho_{0}^{f} \omega^{2} u_{i}^{s(0)}(\boldsymbol{x})-\frac{\partial p^{f(0)}(\boldsymbol{x})}{\partial x_{i}} \\
\frac{\partial w_{i}^{f(0)}}{\partial y_{i}} & =0 \\
w_{i}^{f(0)} & =0 \quad \text { on } \Gamma^{s f}
\end{aligned}
$$

上から順に平衡式, 質量保存則, 固体相との境界における固着条件を表している. 平衡式は線形化された NavierStokes の方程式であり, 右辺は $\boldsymbol{y}$ には依存しないことからミクロスケールにおいては一定の大きさの外力として 作用することを示している. なお，流体は圧縮性と仮定しているが，式 (44) からも分かるようにミクロスケール においては質量保存則から非圧縮の条件が導かれることに注意する。ここで $w_{i}^{f(0)}, p^{f(1)}$ は, 式 (43)の右辺に示 した外力に対する線形性を考慮すると, $\xi_{i}^{k}(\boldsymbol{y}), \pi^{k}(\boldsymbol{y})$ をそれぞれ相対速度, 圧力に関する $Y$-periodic な特性関数と して, 以下のように書くことができる.

$$
\begin{aligned}
w_{i}^{f(0)} & =\xi_{i}^{k}(\boldsymbol{y}) W_{k}(\boldsymbol{x}) \\
p^{f(1)} & =\pi^{k}(\boldsymbol{y}) W_{k}(\boldsymbol{x})
\end{aligned}
$$

ただし, $W_{i}(\boldsymbol{x})=\rho_{0}^{f} \omega^{2} u_{i}^{s(0)}(\boldsymbol{x})-\frac{\partial p^{f(0)}(\boldsymbol{x})}{\partial x_{i}}$ である. これらを式 (43)〜(45) に代入し Galerkin 法を適用すると次に 示す弱形式に帰着することができる.

$$
\begin{aligned}
& \int_{Y} \rho_{0}^{f} j \omega\left[\xi_{i}^{k} W_{k}(\boldsymbol{x})\right][\delta\left.\xi_{i}^{k} W_{k}(\boldsymbol{x})\right] d Y+\int_{Y} \mu^{f}\left[\frac{\partial \xi_{i}^{k}}{\partial y_{j}} W_{k}(\boldsymbol{x})\right]\left[\frac{\partial \delta \xi_{i}^{k}}{\partial y_{j}} W_{k}(\boldsymbol{x})\right] d Y+\int_{Y} \frac{1}{3} \mu^{f}\left[\frac{\partial \xi_{i}^{k}}{\partial y_{i}} W_{k}(\boldsymbol{x})\right]\left[\frac{\partial \delta \xi_{i}^{k}}{\partial y_{i}} W_{k}(\boldsymbol{x})\right] d Y \\
&-\int_{Y}\left[\frac{\partial \xi_{i}^{k}}{\partial y_{i}} W_{k}(\boldsymbol{x})\right] \delta \pi^{k} W_{k}(\boldsymbol{x}) d Y-\int_{Y}\left[\frac{\partial \delta \xi_{i}^{k}}{\partial y_{i}} W_{k}(\boldsymbol{x})\right] \pi^{k} W_{k}(\boldsymbol{x}) d Y=\int_{Y} W_{i}(\boldsymbol{x})\left[\delta \xi_{i}^{k} W_{k}(\boldsymbol{x})\right] d Y
\end{aligned}
$$




$$
\xi_{i}^{k}(\boldsymbol{y}) W_{k}(\boldsymbol{x})=0 \text { on } \Gamma^{s f}
$$

よって, 特性関数 $\xi_{i}^{k}(\boldsymbol{y}), \pi^{k}(\boldsymbol{y})$ は, 上式において $W_{k}(\boldsymbol{x})=1$ として得られる以下の式の解として求めることがで きる.

$$
\begin{gathered}
\int_{Y} \rho_{0}^{f} j \omega \xi_{i}^{k} \delta \xi_{i}^{k} d Y+\int_{Y} \mu^{f} \frac{\partial \xi_{i}^{k}}{\partial y_{j}} \frac{\partial \delta \xi_{i}^{k}}{\partial y_{j}} d Y+\int_{Y} \frac{1}{3} \mu^{f} \frac{\partial \xi_{i}^{k}}{\partial y_{i}} \frac{\partial \delta \xi_{i}^{k}}{\partial y_{i}} d Y-\int_{Y} \frac{\partial \xi_{i}^{k}}{\partial y_{j}} \delta \pi^{k} d Y-\int_{Y} \frac{\partial \delta \xi_{i}^{k}}{\partial y_{j}} \pi^{k} d Y=\int_{Y} \delta \xi_{k}^{k} d Y \\
\xi_{i}^{k}(\boldsymbol{y})=0 \text { on } \Gamma^{s f}
\end{gathered}
$$

なお，前節で述べた固体相の境界值問題と同様に，一定圧力の成分を除くため

$$
\int_{Y} \pi^{k}(\boldsymbol{y}) d Y=0
$$

の条件を付加している.

さて, 式 (50)のように速度と圧力 (ここでは $\xi_{i}^{k}(\boldsymbol{y})$ と $\left.\pi^{k}(\boldsymbol{y})\right)$ がともに独立した未知量となる混合型の問題にお いて, 解を有限要素法により求める場合, 離散化 inf-sup 条件を満足させる必要がある. 一般的には速度に関する 補間関数の次数を, 圧力に関する補間関数の次数より高く設定した要素が用いられる ${ }^{(17)}$. しかし, 速度に高次要 素を用いると, 要素数が増大するに伴い系全体の自由度が大きくなり, 必要な計算資源が増大する. この問題に対 して, Dohrmann と Bochev ${ }^{(18)}$ は圧力に関する安定化項を付加することで, 速度・圧力ともに双一次要素を用いて 離散化し混合型の問題を安定的に解く方法を提案している. 本論文ではこの方法を適用し特性関数 $\xi_{i}^{k}(\boldsymbol{y}), \pi^{k}(\boldsymbol{y})$ を求めることとする.

\section{5 流体相の温度場の境界值問題}

$\varepsilon^{0}$ のオーダーにおける流体相の温度 $\tau^{f(0)}$ は, 圧力 $p^{f(0)}(\boldsymbol{x})$ に対する線形性を考慮すると, $\zeta(\boldsymbol{y})$ を温度に関す る $Y$-periodic な特性関数として次式のように書ける.

$$
\tau^{f(0)}=\frac{1}{\rho_{0}^{f} C_{p}^{f}} \zeta(\boldsymbol{y}) p^{f(0)}(\boldsymbol{x})
$$

これを式 (33) の熱平衡式に代入し Galerkin 法を適用すると以下に示す弱形式を導くことができる.

$$
\int_{Y}-\frac{1}{\rho_{0}^{f} C_{p}^{f}} \kappa_{i j}^{f} \frac{\partial \zeta(\boldsymbol{y})}{\partial y_{j}} p^{f(0)}(\boldsymbol{x}) \frac{\partial \delta \tau^{f}}{\partial y_{i}} d Y=\int_{Y}\left[j \omega \zeta(\boldsymbol{y}) p^{f(0)}(\boldsymbol{x})-j \omega p^{f(0)}(\boldsymbol{x})\right] \delta \tau^{f} d Y
$$

$\Gamma^{s f}$ に打ける温度の連続条件式 (37) も考慮すると, $\zeta(\boldsymbol{y})$ は $p^{f(0)}(\boldsymbol{x})=1$ として得られる次式の解として求めること ができる.

$$
\begin{gathered}
\int_{Y} \frac{1}{j \omega \rho_{0}^{f} C_{p}^{f}} \kappa_{i j}^{f} \frac{\partial \zeta(\boldsymbol{y})}{\partial y_{j}} \frac{\partial \delta \tau^{f}}{\partial y_{i}} d Y+\int_{Y} \zeta(\boldsymbol{y}) \delta \tau^{f} d Y=\int_{Y} \delta \tau^{f} d Y \\
\zeta(\boldsymbol{y})=0 \text { on } \Gamma^{s f}
\end{gathered}
$$

\section{6 固体相の均質化特性}

固体相の均質化された弾性テンソル $\left\langle c_{i j k l}^{s}\right\rangle$ は Terada $~^{(10)}$ と同様, 次式により求めることができる.

$$
\left\langle c_{i j k l}^{s}\right\rangle=\frac{1}{|Y|} \int_{Y}\left[c_{i j k l}^{s}-c_{i j p q}^{s} \frac{\partial \chi_{p}^{k l}(\boldsymbol{y})}{\partial y_{q}}\right] d Y
$$

ここで, $|Y|$ は多孔質体のユニットセル $Y$ の体積, 〈〉は $Y$ における体積平均を表している.

\section{7 流体相の均質化特性}

流体相のマクロな均質化特性としては, 上述したように等価密度と等価体積弾性率を考える. ここでは流体相 のみの特性を考えるため固体相の変位は 0 としても差し支えはない. まず, 式 (46) において $u_{i}^{s(0)}(\boldsymbol{x})$ を 0 とし, $Y$ 
における体積平均をとると，次式を得ることができる.

$$
\left\langle w_{i}^{f(0)}\right\rangle=\left\langle\xi_{i}^{k}(\boldsymbol{y})\right\rangle\left[-\frac{\partial p^{f(0)}(\boldsymbol{x})}{\partial x_{k}}\right]
$$

また, $\left|Y^{f}\right|$ をユニットセル中の流体相 $Y^{f}$ の体積とすると, 空孔率 $\phi$ は $\left|Y^{f}\right| /|Y|$ であるから, この式は以下のよう に書き直すことができる.

$$
\left\langle w_{i}^{f(0)}\right\rangle=\left\langle\xi_{i}^{k}(\boldsymbol{y})\right\rangle_{Y^{f}}\left[-\frac{\partial \phi p^{f(0)}(\boldsymbol{x})}{\partial x_{k}}\right]
$$

ただし，〈 $\rangle_{Y^{f}}$ は $Y^{f}$ における体積平均である. これと式 (2) を比較すると, 等価密度 $\rho^{f c}$ は次式で表すことがで きる.

$$
\rho_{k i}^{f c}=\frac{1}{j \omega}\left\langle\xi_{i}^{k}(\boldsymbol{y})\right\rangle_{Y f}^{-1}
$$

すなわち，等価密度はミクロスケールにおける流体相の相対速度から算出することができる. 粘性などの影響が 大きく相対速度が小さい場合には，見かけ上の質量が大きくなることを意味しており，物理的にも理解が容易で ある. また, Biotのモデルでは材料の等方性を仮定しているため, 式(3)のようにスカラー量として表されるが, 任意のミクロ周期構造を考慮できる本モデルでは上式に示したようにテンソル量となることが分かる.

次に，等価体積弾性率について考える．体積弾性率は一般に圧力と体積ひずみの間の比例定数として定義され ることから，ここでは以下のように書くことができる.

$$
-p^{f(0)}(\boldsymbol{x})=K^{f} \frac{\partial\left\langle u_{i}^{f(0)}\right\rangle_{Y^{f}}}{\partial x_{i}}
$$

以下で $K^{f}$ の具体的な表記を求める. 状態方程式 (35) は, 流体相 $Y^{f}$ における体積平均をとると以下のように書き 直すことができる.

$$
\frac{p^{f(0)}(\boldsymbol{x})}{P_{0}}=\frac{\left\langle\delta^{(0)}\right\rangle_{Y^{f}}}{\rho_{0}^{f}}+\frac{\left\langle\tau^{f(0)}\right\rangle_{Y^{f}}}{T_{0}}
$$

これに，式 (53) の流体相における温度 $\tau^{f(0)}$ の $Y^{f}$ における体積平均

$$
\left\langle\tau^{f(0)}\right\rangle_{Y^{f}}=\frac{1}{\rho_{0}^{f} C_{p}^{f}}\langle\zeta(\boldsymbol{y})\rangle_{Y^{f}} p^{f(0)}(\boldsymbol{x})
$$

を代入し $\tau^{f(0)}$ を消去すると，次式を導くことができる.

$$
-j \omega \frac{\left\langle\delta^{(0)}\right\rangle}{\rho_{0}^{f}}=-j \omega p^{f(0)}(\boldsymbol{x}) \phi \frac{\gamma-(\gamma-1)\langle\zeta(\boldsymbol{y})\rangle_{Y^{f}}}{\gamma P_{0}}
$$

なお, 導出に際しては平衡状態における関係式 $P_{0}=\rho_{0}^{f} C_{p}^{f}(1-1 / \gamma) T_{0}$ を用いている. また, 質量保存則である式 (34)の体積平均から以下の式を得ることができる.

$$
-j \omega \frac{\left\langle\delta^{(0)}\right\rangle}{\rho_{0}^{f}}=\frac{1}{|Y|} \int_{Y} \frac{\partial v_{i}^{f(0)}}{\partial x_{i}} d Y+\frac{1}{|Y|} \int_{\Gamma^{s f}} v_{i}^{f(1)} n_{i}^{f} d \Gamma
$$

境界 $\Gamma^{s f}$ における固着条件式 (20) を考慮すると，固体相の変位が 0 の場合には上式の右辺第 2 項は 0 となり，以 下のように書き直すことができる.

$$
-j \omega \frac{\left\langle\delta^{(0)}\right\rangle}{\rho_{0}^{f}}=\phi \frac{\partial\left\langle v_{i}^{f(0)}\right\rangle_{Y^{f}}}{\partial x_{i}}
$$

これより, 式 (64) と (66) の右辺を等置すると次式を得ることができる.

$$
-p^{f(0)}(\boldsymbol{x}) \frac{\gamma-(\gamma-1)\langle\zeta(\boldsymbol{y})\rangle_{Y^{f}}}{\gamma P_{0}}=\frac{1}{j \omega} \frac{\partial\left\langle v_{i}^{f(0)}\right\rangle_{Y^{f}}}{\partial x_{i}}
$$

よって，これと定義式(61)を比較すると $K^{f}$ は次式で表すことができる.

$$
K^{f}=\frac{\gamma P_{0}}{\gamma-(\gamma-1)\langle\zeta(\boldsymbol{y})\rangle_{Y^{f}}}
$$


すなわち, 流体の等価体積弾性率はミクロスケールにおける流体相の温度分布から算出することができる. この式 表現によれば, ミクロスケールにおいて等温変化する場合, $\left\langle\tau^{f(0)}\right\rangle_{Y^{f}}=0$ であるから式 $(63) よ り\langle\zeta(y)\rangle_{Y^{f}}=0$ と なり, $K^{f}$ は $P_{0}$ となる. また, 断熱変化をする場合はポアソンの法則を考慮すると, 状態方程式より $\langle\zeta(\boldsymbol{y})\rangle_{Y^{f}}=1$ となり， $K^{f}=\gamma P_{0}$ を得ることができる. このようにミクロスケールにおける現象を直接的に反映した表現になっ ており, 物理的にも理解しやすいことが分かる.

\section{5. 数 值 検 証}

固体相の均質化特性については, Terada ${ }^{(10)}$ や Burridge $~^{(11)}$ と同じであるから省略する.ここでは, 流体 相の均質化特性である等価密度 $\rho^{f c}$ と等価体積弾性率 $K^{f}$ につて, 均質化法による数值解と解析解を比較し, モデル化および数值解の精度を検証する. 等価密度, 等価体積弾性率それぞれの解析解 $\rho_{0}^{f c}, K_{0}^{f}$ は, Allard ${ }^{(8)} や$ Stinson ${ }^{(19)}$ によって求められており，F断面形状により決まる関数としてそれぞれ以下の式で与えられる.

$$
\begin{aligned}
\rho_{0}^{f c} & =\frac{\rho_{0}^{f}}{F(v)} \\
K_{0}^{f} & =\frac{\gamma P_{0}}{\gamma-(\gamma-1) F\left(v^{\prime}\right)}
\end{aligned}
$$

なお, 多孔質体の微視構造は解析解を求めることができる, 均一なスリット形断面, 矩形断面または円形断面の 流路を有するものを用いる.

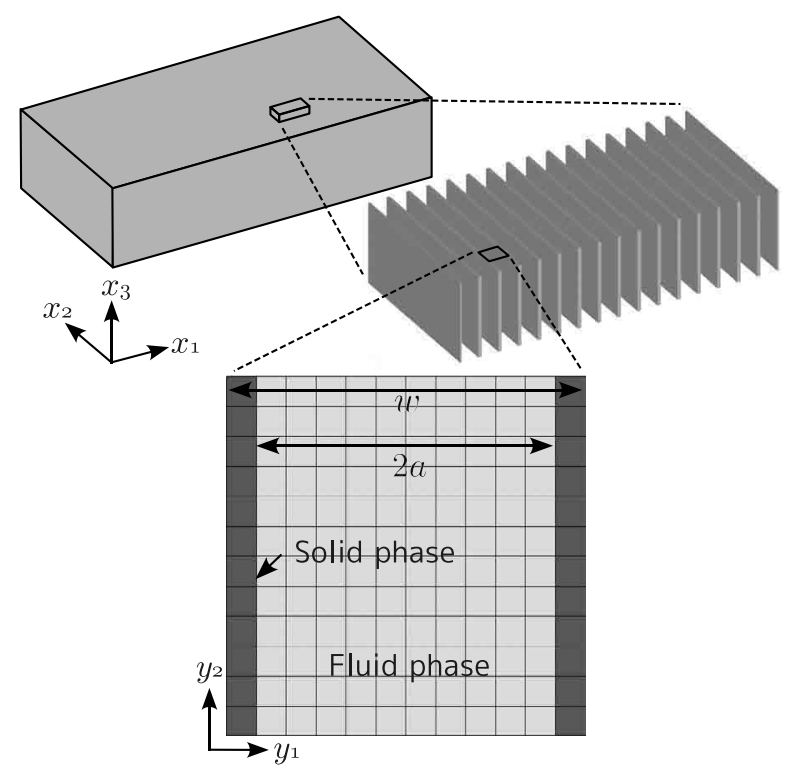

Fig. 1 Poroelastic material with fluid phase in slit section.

\section{$5 \cdot 1$ スリット形断面}

まず，図 1 に示すように，一辺が $w$ の正方形状のユニットセル中に，幅 $2 a$ のスリット形の均一断面を有する流 体相が存在する多孔質吸音材を考える. なおここでは, 解析解と比較するため, 各相の運動は $z$ 軸方向のみを考 えるものとする. したがって, $x$ 軸方向には流路が連結していないが問題はない. この場合, 解析解における関数 $F$ は次式で与えられる.

$$
F(\eta)=1-\frac{\tanh (\alpha a)}{\alpha a}, \alpha=\left(\frac{j \omega}{\eta}\right)^{1 / 2}
$$

数值解はユニットセルを四辺形要素により離散化した有限要素モデルにより求める. ユニットセル各辺の分割 数は $12 ， 24 ， 48 ， 96$ の 4 パターンとし数值解の収束性もあわせて検証する. なお, 図 1 には分割数が 12 の場合 のモデルを示している. ユニットセルおよび流路の大きさは, 代表的な多孔質吸音材の微視構造のスケールを考 慮し, $w=120 \mu \mathrm{m}, 2 a=100 \mu \mathrm{m}$ とする.

図 2 の上段に式 (60) による等価密度 $\rho^{f c}$, および下段に式 (68) による等価体積弾性率 $K^{f}$ の解析解との相対誤 
差を示す. 要素分割が粗い場合でも, $1 \%$ 以内の䛊差であり, 非常に良い精度で数值解を得られていることが分か る. また，数值解は分割数が増加するにつれて解析解へ収束することが確認できる.
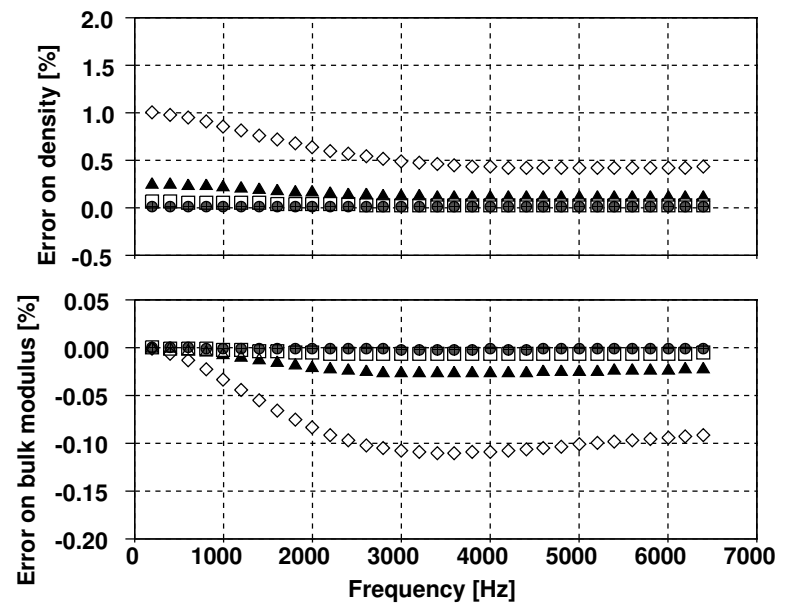

Fig. 2 Relative error in density $\rho^{f c}$ and bulk modulus $K^{f}$ for fluid phase in slit section. Number of elements per unit cell side is $12(\diamond), 24(\boldsymbol{\bullet}), 48(\square), 96(\bullet)$.

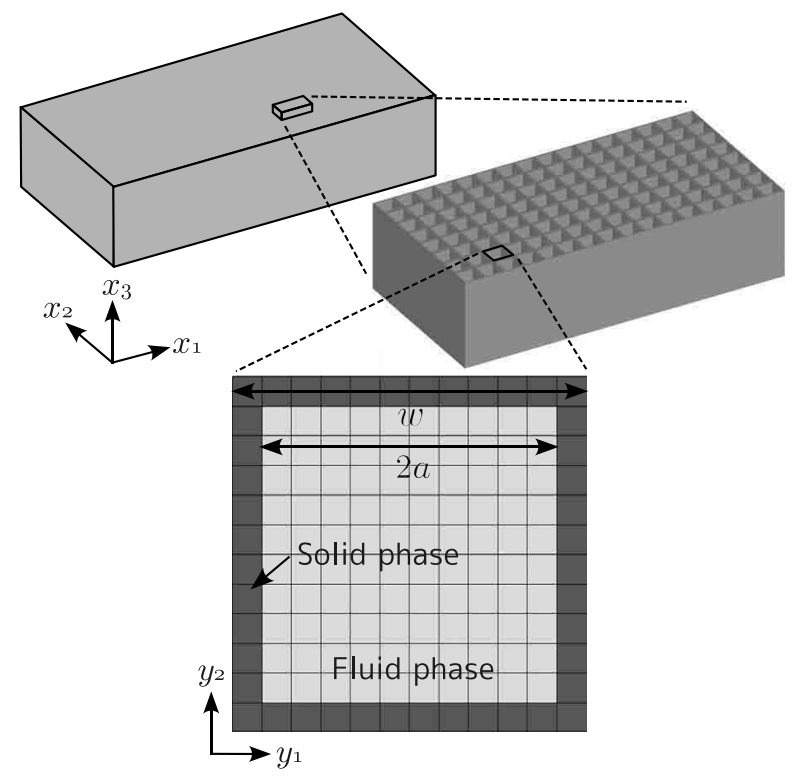

Fig. 3 Poroelastic material with fluid phase in rectangular section.

\section{2 矩形断面}

次に, 図 3 に示すように, 一辺が $w$ の正方形状のユニットセル中に, 横 $2 a$, 縦 $2 b$ の大きさの矩形断面を有す る流体相が存在する多孔質吸音材を考える. この場合, 解析解における関数 $F$ は次式で与えられる.

$$
F(\eta)=\sum_{i=0}^{\infty} \sum_{j=0}^{\infty} \frac{4 j \omega}{\eta a^{2} b^{2}} \frac{1}{\alpha_{i}^{2} \beta_{j}^{2}\left(\alpha_{i}^{2}+\beta_{j}^{2}+\frac{j \omega}{\eta}\right)}, \alpha_{i}=\left(i+\frac{1}{2}\right) \frac{\pi}{a}, \beta_{j}=\left(j+\frac{1}{2}\right) \frac{\pi}{b}
$$

数值解はユニットセル各辺を四辺形要素で $12,24,48,96$ 分割する 4 パターンについて求める. ここでは, $w=120 \mu \mathrm{m}, 2 a=2 b=100 \mu \mathrm{m}$ とし, 図 3 には分割数が 12 の場合のモデルを示している.

図 4 の上段に等価密度 $\rho^{f c}$, 下段に等価体積弾性率 $K^{f}$ の解析解との相対誤差を示しており, スリット形断面の 場合と同程度の精度良い解が得られている. 

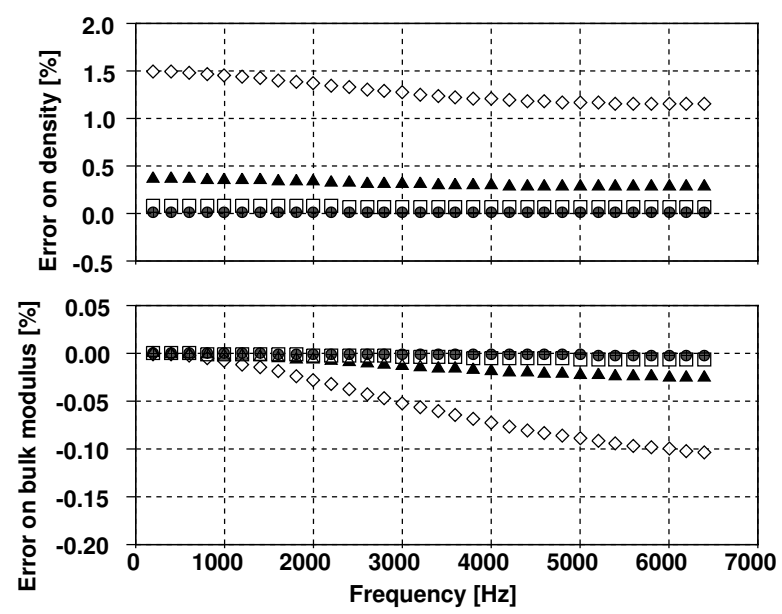

Fig. 4 Relative error in density $\rho^{f c}$ and bulk modulus $K^{f}$ for fluid phase in rectangular section. Number of elements per unit cell side is $12(\diamond), 24(\boldsymbol{\Lambda}), 48(\square), 96(\bullet)$.

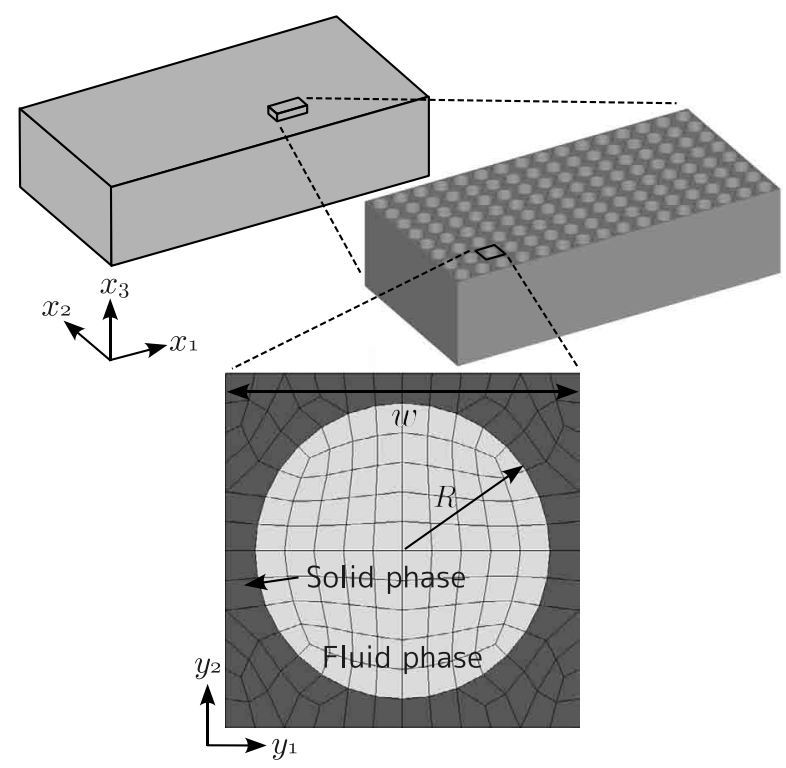

Fig. 5 Poroelastic material with fluid phase in circular section.

\section{$5 \cdot 3$ 円形断面}

最後に, 図 5 に示すように, 一辺が $w$ の正方形状のユニットセル中に, 半径 $R$ の大きさの円形断面を有する流 体相が存在する多孔質吸音材を考える. この場合, 解析解における $F$ は次式で与えられる.

$$
F(\eta)=1-\frac{2}{\alpha R} \frac{J_{1}(\alpha R)}{J_{0}(\alpha R)}, \alpha=\left(-\frac{j \omega}{\eta}\right)^{1 / 2}
$$

ただし， $J_{i}$ は $i$ 次の Bessel 関数である.

数值解は, 上述したモデルと同様, ユニットセルの各辺を $12,24,48,96$ 分割する 4 パターンについて求める. ここでは, $w=120 \mu \mathrm{m}, 2 R=100 \mu \mathrm{m}$ とし，図 5 には分割数が 12 の場合のモデルを示している. 図 6 に示すよ うに, 他の断面形状の場合と同程度の精度良い解が得られていることが分かる. また, 数值解が解析解へ収束す ることも分かる.

実際の微視構造を反映する場合には， $\mu \mathrm{X}$ 線 CT などを利用したイメージベースモデル ${ }^{(20)}$ が有効と考えられる. この場合, 立方体形状のボクセルを一つの要素とするため, 形状を正確に表現できず, 解像度が十分でない場合 には誤差の要因となる。ここでは, 円形断面の流体相を有する多孔質吸音材をボクセルメッシュによりモデル化 した場合の精度について検討する. 図7(a)〜(d) はそれぞれ，ユニットセル各辺の分割数が 12，24，48，96 の場 

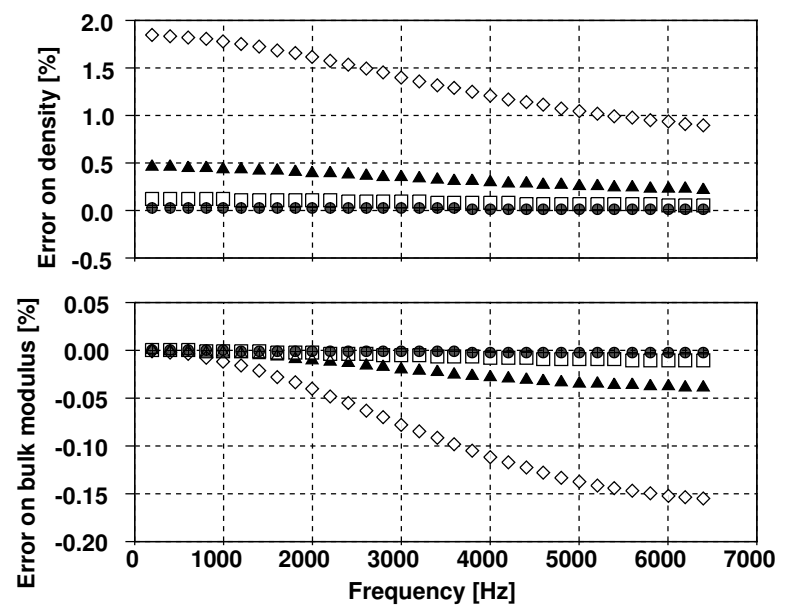

Fig. 6 Relative error in density $\rho^{f c}$ and bulk modulus $K^{f}$ for fluid phase in circular section. Number of elements per unit cell side is $12(\diamond), 24(\boldsymbol{\Lambda}), 48(\square), 96(\bullet)$.

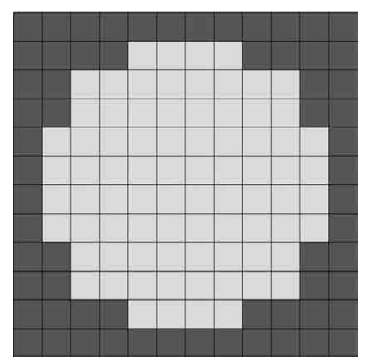

(a)

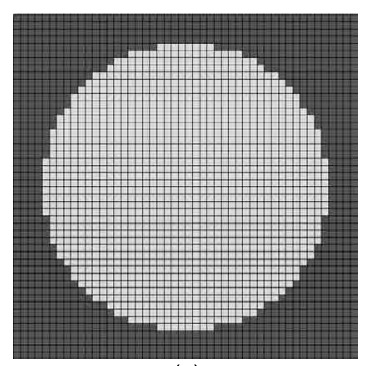

(c)

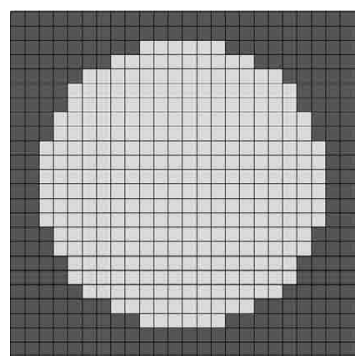

(b)

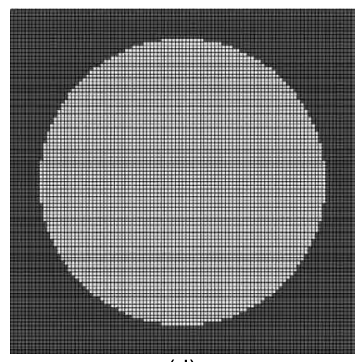

(d)

Fig. 7 Voxel mesh model for poroelastic material with fluid phase in circular section. Number of elements per unit cell side is (a) 12 , (b) 24 , (c) 48 , (d) 96.

合のモデルを示している. 図 8 の上段に等価密度 $\rho^{f c}$, 下段に等価体積弾性率 $K^{f}$ の解析解との相対䛊差を示して おり, 図 6 に示した結果と比較すると一枌精度が悪化しているものの, 誤差の大きさは分割数が 24 の場合で $8 \%$ 以内であり十分実用の範囲内である. 実際には計算資源と計算精度のバランスを考慮して分割数すなわち解像度 を決める必要があると考えられる。

\section{6. 結言}

本論文では, 多孔質吸音材を対象にした現在の Biot のモデルにおいて, 等価密度や等価体積弾性率が, 5 つの パラメータによる経験的な関数で表現されていることに対して, 均質化法により微視構造から直接的に等価特性 を導出する手法を提案し, 数值例によりその手法の有効性を検証した. 得られた結果を以下にまとめる.

(1) 多孔質吸音材の微視構造に漸近展開法に基づく均質化法を適用し, 流体相で生じる粘性による減衰および 熱散逸による減衰の両方を考慮した定式化を行った.

(2) 流体相の等価密度は速度に関する特性関数，等価体積弾性率は温度に関する特性関数のみを用いた式 (60) および (68)で与えられることを示した. 

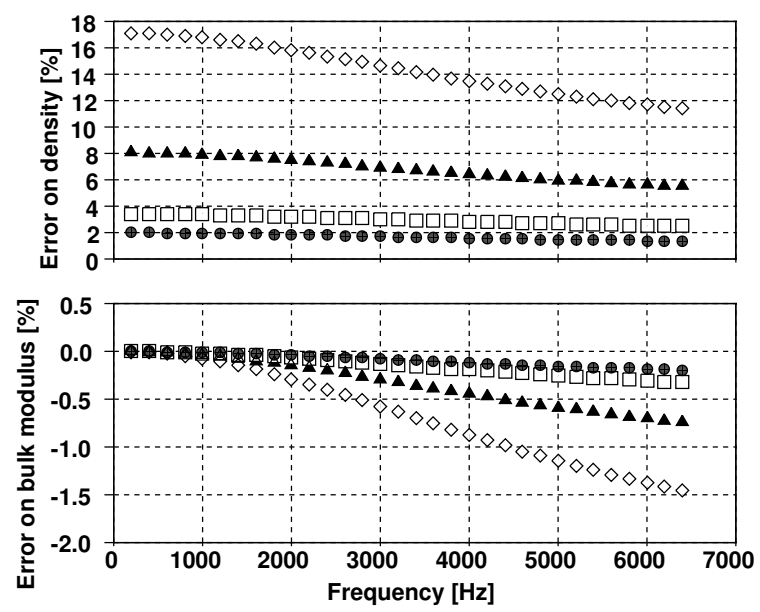

Fig. 8 Relative error in density $\rho^{f c}$ and bulk modulus $K^{f}$ for fluid phase in circular section calculated using voxel mesh model. Number of elements per unit cell side is $12(\diamond), 24(\boldsymbol{\Delta}), 48(\square), 96(\bullet)$

（3）解析解を得ることのできる, 二次元的で均一な流路形状からなる微視構造を用いて, 提案手法による数值 解と解析解を比較検証した結果, 良い精度で数值解を求めることができること, および数值解が理論解に収束す ることを確認でき，手法の有効性を実証することができた。

\section{文献}

(1) Kang, Y. J. and Bolton, J. S., Finite element modeling of isotropic elastic porous materials coupled with acoustical finite elements, Journal of Acoustical Society of America, Vol. 98 (1995), pp. 635 - 643.

(2) Easwaran, V., Lauriks, W. and Coyette, J. P., Displacement-based finite element method for guided wave propagation problems: Application to poroelastic media, Journal of Acoustical Society of America, Vol. 100 (1996), pp. 2989 3002 .

(3) Atalla, N., Panneton, R. and Debergue, P., A mixed displacement-pressure formulation for poroelastic materials, Journal of Acoustical Society of America, Vol. 104 (1998), pp. 1444 - 1452.

(4) Biot, M. A., Theory of propagation of elastic waves in a fluid-saturated porous solid. I.Low-frequency range, Journal of Acoustical Society of America, Vol. 28 (1956), pp. 168 - 178.

(5) Biot, M. A., Theory of propagation of elastic waves in a fluid-saturated porous solid. II. Higher frequency range, Journal of Acoustical Society of America, Vol. 28 (1956), pp. 179 - 191.

(6) Johnson, D. L., Koplik, J. and Dashen, R., Theory of dynamic permeability and tortuosity in fluid-saturated porous media, Journal of Fluid Mechanics, Vol. 176 (1987), pp. 379 - 402.

(7) Champoux, Y. and Allard, J. F., Dynamic tortuosity and bulk modulus in air-saturated porous media, Journal of Applied Physics, Vol. 70 (1991), pp. 1975 - 1979.

(8) Allard, J. F., Propagation of Sound in Porous Media, (1993), Elsevier Applied Science.

(9) Auriault, J. L., Borne, L. and Chambon, R., Dynamics of porous saturated media, checking of the generalized law of darcy, Journal of Acoustical Society of America, Vol. 77 (1985), pp. 1641 - 1650.

(10) Terada, K., Ito, T. and Kikuchi, N., Characterization of the mechanical behaviours of solid-fluid mixture by the homogenization method, Computer Methods in Applied Mechanics and Engineering, Vol. 153 (1998), pp. 223 257.

(11) Burridge, R. and Keller, J. B., Poroelasticity equations derived fron microstructure, Journal of Acoustical Society of America, Vol. 70 (1981), pp. 1140 - 1146.

(12) 山本 崇史, 丸山 新一, 泉井一浩, 西脇 眞二, 寺田賢二郎, マルチスケール解析による多孔質吸音材モデル, 日本 機械学会論文集 (C 編), 76 巻 768 号 (2010), pp. $2039-2048$. 
(13) Castagnéde, B., Moussatov, A., Lafarge, D. and Saeid, M., Low frequency in situ metrology of absorption and dispersion of sound absorbing porous materials based on high power ultrasonic non-linearly demodulated waves, Applied Acoustics, Vol. 69 (2008), pp. $634-648$.

(14) Gilbert, R. P. and Mikelić, A., Homogenizing the acoustic properties of the seabed: Part I, Nonlinear Analysis, Vol. 40 (2000), pp. $185-212$.

(15) Clopeau, T., Ferrín, J. L., Gilbert, R. P. and Mikelić, A., Homogenizing the acoustic properties of the seabed: Part II, Mathematical and Computer Modelling, Vol. 33 (2001), pp. 821 - 841.

(16) 寺田賢二郎, 菊池昇, 均質化法入門, (2003), 丸善.

(17) 渡辺 浩志, 久田 俊明, 混合型有限要素解の安定条件の数值解析, 日本機械学会論文集 (A 編), 61 巻 583 号 (1995), pp. $660-667$.

(18) Dohrmann, C. R. and Bochev, P. B., A stabilized finite element method for the stokes problem based on polynomial pressure projections, International Journal for Numerical Methods in Fluids, Vol. 46 (2000), pp. 183 - 201.

(19) Stinson, M. R., The propagation of plane sound wave in narrow and wide circular tubes, and generalization to uniform tubes of arbitrary cross-sectional shape, Journal of Acoustical Society of America, Vol. 89 (1991), pp. 550 -558 .

(20) Hollister, S. J. and Kikuchi, N., Homogenization theory and digital imaging : A basis for studying the mechanics and design principles of bone tissue, Biotechnology and Bioengineering, Vol. 43 (1994), pp. 586 - 596. 